\title{
Ultra-Thin Veneers: A Current State-of-the-Art
}

\author{
Laminados Ultrafinos: Un Estado del Arte Actualizado
}

\author{
Eduardo Borie'; Daniela Santamaría; Eduardo Rosas³; Fernando Grandón ${ }^{4}$ \& Benjamín Weber ${ }^{1}$
}

BORIE, E.; SANTAMARÍA, D.; ROSAS, E.; GRANDÓN, F. \& WEBER, B. Ultra-thin veneers: a current state-of-the-art. Int. J. Odontostomat., 15(4):898-903, 2021.

ABSTRACT: Currently, the aesthetic requirements of patients are increasing and they have begun to request more conservative treatments. One alternative to achieve harmonious results is through the indication of ultra-thin veneers. This is considered a conservative technique but the evidence basis for it seems to be limited. The following review attempts to summarize the relevant literature to establish guidelines for clinicians based on scientific evidence regarding the use of ultrathin veneers. Ultra-thin veneers seem to be a reliable alternative to achieve aesthetic and harmonious results; however, many factors must be considered to ensure correct diagnosis and treatment plan. In addition, the literature is scarce in relation to a consensus on tooth preparation and long-term studies evaluating the success of this type of treatment over time do not exist.

KEY WORDS: aesthetic, ceramics, contact lens, laminate, ultra-thin veneers.

\section{INTRODUCTION}

In the last decades, dental patients have increasingly been looking to improve their appearance (Alencar et al., 2014). This aesthetic demand has been associated with the request for more conservative treatments, which can be answered by several conservative techniques (McLaren \& LeSage, 2011; Cooper, 2013). A novel conservative technique, i.e., ultra-thin veneers, has great potential for treating aesthetically displeasing anterior teeth. This technique, also called "dental contact lens", employs no or minimal tooth preparation and achieves satisfactory functional and aesthetic results (Alencar et al.). In this sense, ultra-thin veneers may be a valuable combination between minimal invasiveness and favorable aesthetics, thus leading to optimal results in several cases (McLaren \& LeSage). It is important to point out that the correct indication for this treatment according to remaining conservation of tooth structure and clinical needs seems to be critical for each case.

The development of ultra-thin venners is a direct consequence of improvements in dental adhesives and luting agents. Since 1930, laminate veneers have been used to improve the appearance of teeth without much success due to the absence of adhesion. Only since 1980, with the discovery of etching and resins bis-GMAbased, treatments with laminate veneers are now considered as a minimally invasive and definitive treatment (Layton et al., 2012).

This technique has become popular because contemporary dental materials materials allow for the fabrication of restorations with minimum thickness for preparations of $0.3 \mathrm{~mm}$ or even less. The versatility of ultra-thin veneers can be highlighted by the possibility of combining them to other interventions. Favorable aesthetic outcomes can be further enhanced by associating other procedures to ultra-thin veneers, like vital tooth whitening, gingival and incisal recontouring and orthodontics (Christensen, 2008).

In spite of potential advantages, the recent introduction of ultra-thin veneers as an oral health intervention raises question over previous studies that

\footnotetext{
${ }^{1} \mathrm{CICO}$ Research Centre, Integral Dentistry Deparment, Universidad de La Frontera, Temuco, Chile.

2 Private practice, Temuco, Chile.

${ }^{3}$ Programa de Magister en Odontología, Facultad de Odontología, Universidad de La Frontera, Temuco, Chile.

${ }^{4}$ Facultad de Odontología, Universidad de Concepción, Concepción, Chile.
} 
provide basis for their use. Details on their exact indication or involved procedures may be heterogeneous in different studies and be associated with different aesthetic results or long-term success rates.

Preparations for veneers are divided into three generations. The first generation corresponds to a nonindividualized and aggressive preparation with buccal and incisal wear, indicated for conventional veneers; this wear included enamel and dentin. Its function was to restore the contour of the tooth, that was prepared until getting a uniform thickness of material restoration, depending on tooth remnant. The second generation corresponds to an accurate analysis and planning of dental preparation, by a diagnostic wax-up and silicon index fabrication. In the third generation, the enamel preservation was considered in the teeth volume restoration (Coachman et al., 2014).

When there is no disease and principally for aesthetic reasons, contact lens may be an interesting alternative, with minimal invasiveness, to restore the aesthetic region (Burke, 2012). However, every case is different and is necessary to consider teeth position, alignment, symmetry, proportion, shape, color and texture (Schoenfeld et al., 2006; Okida et al., 2012).

The following review attempts to summarize the relevant literature to establish guidelines for clinicians based on scientific evidence regarding the use of ultra-thin veneers.

Features: The new technologies allow us to have improvements in particle distribution and size, coefficient of thermal expansion, firing temperature and color pigment, providing more crack resistance and aesthetic properties to the new ceramic materials. With these characteristics, the "contact lens effect" can be achieved, where more translucent and less opaque materials are indicated, and light transmission is not interfered (Barghi \& McAlister, 1998; da Cunha et al., 2013). Ultra-thin veneers have the features of most conventional veneers, differing in some details such as thickness, wear and indications. Generally, the thickness of a "contact lens" is $0.3 \mathrm{~mm}$, regardless if the tooth has no preparation or minimal preparation (Christensen). That is the reason because this type of treatment offers a high aesthetic potential, because it improves light transmission and preserves the optical conditions of natural teeth. The selected materials are mainly feldspathic porcelain and lithium disilicate because of greater potential to reproduce the natural features and transparency of the tooth. Depending on the final restoration thickness, the choice of cement color is important, being the most recommended the translucent cement whenever it not interferes with the final result (Cardoso et al., 2009; Lee \& Choi, 2018).

The materials used in ultra-thin veneers must have similar characteristics to the tooth structure and excellent adhesive properties. Principally, these features are related to the use of hydrofluoric acid and silane. This way, resistance is granted by the monoblock formed by the tooth-restoration junction (Cardoso et al.). Then, if the ultra-thin veneer is bonded to the etched enamel, adhesive fractures are rarely observed (Burke). However, resistance may be reduced in the teeth, for example, when subjected to endodontic treatment (D'Arcangelo et al., 2010). In this case, the treatment may be limited by the quantity of lost tissue as well as the color changes. It is important to consider the integrity of the tooth structure and color, and to choose the correct treatment to achieve both aesthetic and functional success (Re et al., 2014).

If the reduction of the tooth structure is considered for a ultra-thin laminate veneer, it should not exceed $0.3 \mathrm{~mm}$. As a general rule, it is necessary to save the maximum of tooth structure as far as possible because this will provide better aesthetics, resistance and functional outcome (Nash, 2003; Lerner, 2006). Therefore, no deep scuffs are made, but only superficial, leaving slightly rounded corners (Nash). When the margin of the preparation and restoration has an optimal integration, the finishing and contour are achieved easily (Okida et al.).

Moreover, reduction must always should be in enamel and, whenever possible, should never affect the dentin, which gives clinicians some advantages such as maintaining the tooth free of symptomatology, creating a smooth emergency profile and adequate gingival contour, which prevents periodontal damage (Okida et al.). When teeth do not lose the enamel, their biological properties and resistance to stress are maintained; deformation is also prevented, ensuring a long-term treatment benefit (Gresnigt et al., 2011). The amount of tooth remnants and the design preparation have effects on the treatment outcome; therefore, ultra-thin veneers may be indicated when exists enough enamel. Also, some researches (Morita et al., 2016; Albanesi et al., 2016; Blunck et al., 2020) support that minimal and homogeneous tooth wear limited to enamel reduce the risks of fracture and debonding and increase the survival rate. 
Periodontal integration is one of the most favorable characteristics, because the margins are, generally, supragingival providing adequate health to periodontal tissues (Materdomini \& Friedman, 1995; Friedman, 1995; Javaheri et al., 2007; da Cunha et al.; $\operatorname{Re} e t$ al.).

Usually three visits are necessary, mainly for diagnosis and treatment planning. In the first session, an evaluation of the patient's requests and expectations, periodontal examination, photographs, modeling and waxing-up can be performed. Once all these elements are obtained, the clinician can determine the need and amount of tooth preparation, with an accurate treatment plan, according to the patient's requirements. The second visit is for preparation (if needed) and impression, and the last session is intended for cementation (Gresnigt et al., 2011; da Cunha et al.).

Advantages. There are some advantages related to the use of ultra-thin veneers (Christensen; da Cunha et al.; Morita et al.):

- The procedure does not require anesthesia because the amount of enamel removed is small, leading to a reduction of patient's fear.

- It is a fast technique, painless, without pulp damage and sensitivity symptoms.

- Impression is easy, because there is no strict need for tissue management.

- Bonding is only to the enamel; therefore, resulting to longer-lasting restorations and minimal flexing stress.

- The restoration is resistant to permanent staining, with an excellent aesthetic feature and is easy to clean.

- High level of patient acceptance, especially in patients with dental phobia.

Disadvantages: The disadvantages are related to the preparation type such as (Christensen):

- Marginal pigmentation and loss of color stability in cases with insufficient finishing and polishing and/or in patients with poor oral hygiene (Granell-Ruiz et al., 2010; Gurel et al., 2012) or smoking habits in the longterm (Gresnigt et al., 2019).

- Over-contoured or bulky appearance, mainly in no preparation cases or insufficient enamel reduction.

- Periodontal problems in over-contoured restorations.

- If the tooth has no preparation, it is difficult for the technician to determine the limit of gingival margin.
- Some occlusal alterations in unprepared teeth may be undetected by the clinician.

- Not indicated in significant color alterations because it may not be unmasked, mainly because of the veneer's thickness.

If the advantages and disadvantages are analyzed, ultra-thin veneers are indicated in specific patients and not for all cases (Christensen; Javaheri).

Longevity: Alencar et al., reported an evaluation of one-year follow-up of ultra-thin veneers, observing color stability and no marginal failures, without infiltrations, gaps or gingival inflammation. Okida et al., concluded that no sample staining or deterioration was identified in a 3-year follow-up study of ultra-thin veneers. Cardoso et al., stated that the amount of tooth enamel is directly related to long-term success in conventional veneers. Some authors (Strasseler et al., 2007; Aslan et al., 2019; Blunck et al.) reported between 94 \%-97 $\%$ survival rate for minimally invasive porcelain veneers. However, the researches that report a follow-up of treatments of ultra-thin veneers are scarce and no longterm studies evaluating the success over time are published in the literature.

Indications: First, a correct diagnosis is essential for a right treatment planning (Bahillo et al., 2014). The success of this technique is related to the handling of the details: the correct planning case, minimally invasive preparation, accurate selection of materials and methods of cementation, accurate finishing and polishing and planning future controls (Farronato et al., 2012; Burke). Moreover, it is necessary to consider patient age and expectations, the type of occlusion, tooth characteristics, gingival biotype and type of smile (De Andrade et al., 2012). The adhesive bonding to enamel is the most important benefit of no preparation or minimal preparation; therefore, the substrate is an important factor.

Ultra-thin veneers are usually indicated for reestablishment of an aesthetic smile, enhancing a patient's appearance (Alencar et al.). It can also be used in patients with dental erosion and attrition, depending on its severity (Bahillo et al.). This is an important issue, because nowadays, the diet is too acidic which causes more tooth erosion and wear (O'Toole \& Mullan, 2018; Martignon et al., 2019) and ultra-thin veneers can be an alternative to restore only the lost tissue. Patients with malformed teeth, diastema (Fig. 1), enamel fractures or minor chipping, minor rotations of anterior teeth and III, IV, V class 

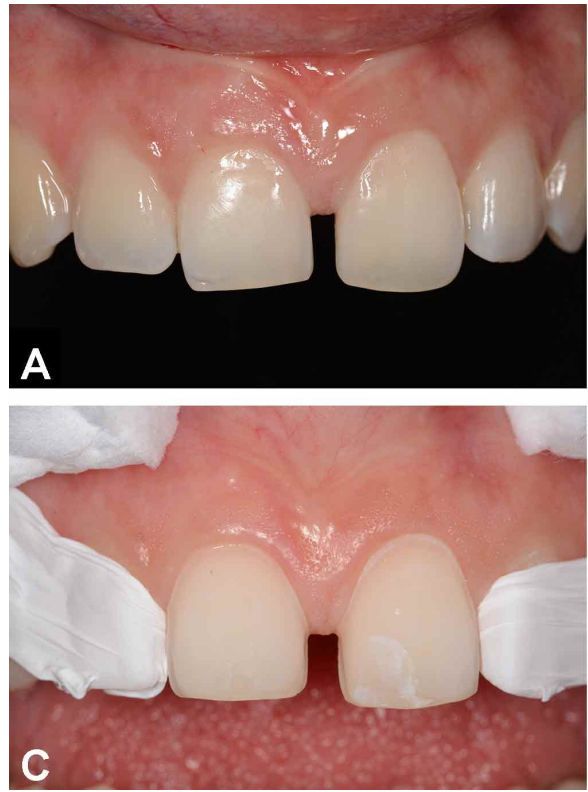

B
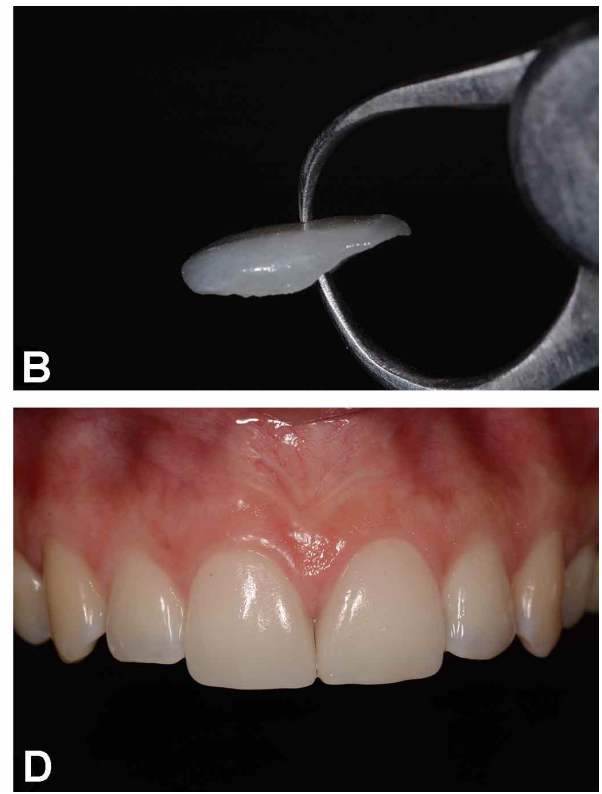

Fig. 1. Ultra-thin veneers indicated in a patient with diastema between both central incisors. A. Initial condition; B. Ultra-thin veneer of $0.2 \mathrm{~mm}$; C. Prepared teeth before cementation; D. Cemented and in harmony with adjacent teeth.

restorations, could be treated with ultra-thin veneers. Anterior small teeth, teeth in lingual position and discrepancies in shape and form could be indications for this type of treatment (Christensen; Burke; Pini et al., 2012).

Furthermore, with this technique, teeth contours can be changed; better arch-forms can be created; widened buccal corridors can be achieved; incisal edge lengths can be altered; teeth alignment for function recovery can be improved; and the superficial enamel surface can be varied (Re et al.).

Ultra-thin veneers are not indicated for discolored teeth because it produces a monotone effect (Christensen) and by its limited masking capacity (Cardoso et al.). In these cases, some options may be used to "improve" the chroma difference such as (a) increase of tooth wear; b) use of a low translucent ceramic; and (c) cement color, all of these with their proper limitations. Tooth integrity and color are critical factors that will interfere with the esthetical results of the treatment with ultra-thin veneers (Cardoso et al.; Re et al.).

No preparation vs minimal preparation: Some researches (Nash; Alencar et al.; Lee \& Choi) have reported no preparation of teeth for ultra-thin veneer treatment. Thus, Nash stated that if there are irregular or deficient areas in the unprepared tooth, this is filled replace it with a new veneer but this time considering tooth preparation. In this sense, the authors of this review concur with these researches and believe that an unprepared tooth may create microscopic problems of adaptation by the cervical over-contour, appearing as an over-lapped profile between the ultra-thin veneer and enamel surface, which will be filled with an extensive line of cement. This cement line may be exposed to buccal environment, leading to dissolution of resin matrix and hydrolysis of bonds (Gurel et al.), causing discoloration and possible infiltration of restoration over time. Unfortunately, long-term studies in the literature to support our hypothesis do not exist.

One of the reasons why clinicians prefer to make a minimal preparation is because it allows seeing the limits, the position of the restoration in the correct place and creates a correct path of insertion (Bahillo et al.). A minimally invasive preparation corresponds to a wearing of approximately 0.1 to $0.3 \mathrm{~mm}$ in the cervical area and $0.3 \mathrm{~mm}$ in the buccal area, creating a natural looking tooth and preserving the dental tissue (Kacker et al., 2011; Okida et al.). In addition, some preparation guidelines recommend a slight labial enamel reduction to reduce bulges (Burke), a slightly rounded preparation of corners and a gentle design of gingival margin (Okida et al.). Subsequently, the margins need to be polished and contacts must be checked (Okida et al.; Re et al.).

A recent method called "aesthetic pre-evaluative temporary" (APT) technique was reported by Gurel et 
al. which uses the mock-up to guide and define the quantity of dental wearing, and it seems to show good clinical results in other studies (Gresnigt et al., 2011; Veneziani, 2017) without unnecessary enamel wear.

Finally, when ultra-thin veneers are cemented, the position, anatomical shape, marginal adaptation, contour, color and aesthetic harmony must be evaluated (Alencar et al.). Thus, when treatment is planned and executed correctly, the aesthetic results can be achieved with ultra-thin veneers, providing a natural and harmonious characterization, both in the tooth and in the patient (Kacker et al.).

\section{CONCLUSIONS}

Within the limitations of this review, the following conclusions may be drawn:

- The literature is scarce in relation to researches that report a follow-up of treatments and long-term studies evaluating the success over time do not exist.

- There is no consensus to define if a no-preparation veneer or with minimal preparation of teeth is recommended.

Aesthetic dentistry should be practiced in the most conservative way possible. In this sense, ultra-thin veneers seem to be a reliable alternative to conserve tooth structure and achieve aesthetic and harmonious results; however, many factors must be considered to ensure correct diagnosis for proper planning before the indication of this type of treatment.

ACKNOWLEDGMENTS. The study was partially supported by Dirección de Investigación, Universidad de La Frontera.

BORIE, E.; SANTAMARÍA, D.; ROSAS, E.; GRANDÓN, F. \& WEBER, B. Laminados ultrafinos: Un estado del arte actualizado. Int. J. Odontostomat., 15(4):898-903, 2021.

RESUMEN: Actualmente, los requisitos estéticos de los pacientes han aumentando y solicitan tratamientos más conservadores. Una alternativa para lograr resultados armónicos es mediante la indicación de carillas o laminados ultrafinos. Esta se considera una técnica conservadora, pero la base teórica parece ser limitada. La siguiente revisión intenta resumir la literatura relevante para establecer pautas para clínicas basadas en evidencia científica sobre el uso de carillas ultrafinas. Las carillas ultrafinas parecen ser una alternativa confiable para lograr resultados estéticos y armónicos; sin embargo, se deben considerar muchos factores para asegurar un diagnóstico y plan de tratamiento correcto. Además, la literatura es escasa en relación a un consenso sobre la preparación dental y no existen estudios a largo plazo que evalúen el éxito de este tipo de tratamiento a lo largo del tiempo.

PALABRAS CLAVE: estética; cerámica; lentes de contacto; laminados; carillas ultrafinas.

\section{REFERENCES}

Albanesi, R. B.; Pigozzo, M. N.; Sesma, N.; Laganá, D. C. \& Morimoto, $\mathrm{S}$. Incisal coverage or not in ceramic laminate veneers: A systematic review and meta-analysis. J. Dent., 52:1-7, 2016.

Alencar, M. S.; Araújo, D. F.; Maenosono, R. M.; Ishikiriama, B. L.; Francischone, C. E. \& Ishikiriama, S. K. Reestablishment of esthetics with minimum thickness veneers: a one-year follow-up case report. Quintessence Int., 45(7):593-7, 2014.

Aslan, Y. U.; Uludamar, A. \& Özkan, Y. Retrospective analysis of lithium disilicate laminate veneers applied by experienced dentists: 10-year results. Int. J. Prothodont., 32(6):471-4, 2019.

Bahillo, J.; Jané, L.; Bortolotto, T.; Krejci, I. \& Roig, M. Full-mouth composite rehabilitation of a mixed erosion and attrition patient: a case report with v-shaped veneers and ultra-thin CAD/CAM composite overlays. Quintessence Int., 45(9):749-56, 2014.

Barghi, N. \& McAlister, E. Porcelain for veneers. J. Esthet. Dent., 10(4):191-7, 1998.

Blunck, U.; Fischer, S.; Hajtó, J.; Frei, S. \& Frankenberger, R. Ceramic laminate veneers: effect of preparation design and ceramic thickness on fracture resistance and marginal quality in vitro. Clin. Oral Investig., 24(8):2745-54, 2020.

Burke, F. J. T. Survival rates for porcelain laminate veneers with special reference to the effect of preparation in dentin: a literature review. J. Esthet. Restor. Dent., 24(4):257-65, 2012.

Cardoso, J. A.; Almeida, P. J.; Fernandes, S.; Silva, C. L.; Pinho, A.; Fischer, A. \& Simões, L. Co-existence of crowns and veneers in the anterior dentition: case report. Eur. J. Esthet. Dent., 4(1):1226,2009

Christensen, G. J. Thick or thin veneers? J. Am. Dent. Assoc., 139(11):1541-3, 2008.

Coachman, C.; Gurel, G.; Calamita, M.; Morimoto, S.; Paolucci, B. \& Sesma, N. The influence of tooth color on preparation design for laminate veneers from a minimally invasive perspective: case report. Int. J. Periodontics Restorative Dent., 34(4):453-9, 2014.

Cooper, C. Ultraconservative dentistry using "no-prep" porcelain veneers. J. Cosmet. Dent., 28:36-42, 2013.

D'Arcangelo, C.; De Angelis, F.; Vadini, M.; D'Amario, M. \& Caputi, $\mathrm{S}$. Fracture resistance and deflection of pulpless anterior teeth restored with composite or porcelain veneers. J. Endod., 36(1):153-6, 2010.

da Cunha, L. F.; Reis, R.; Santana, L.; Romanini, J. C.; Carvalho, R. M. \& Furuse, A. Y. Ceramic veneers with minimum preparation. Eur. J. Dent., 7(4):492-6, 2013.

De Andrade, O. S.; Hirata, R.; Celestrino, M.; Seto, M.; Siqueira Jr., S. \& Nahas, R. Ultimate ceramic veneer: a laboratory-guided preparation technique for minimally invasive laminate veneers. J. Calif. Dent. Assoc., 40(6):489-94, 2012. 
Farronato, D.; Mangano, F.; Pieroni, S.; Lo Giudice, G.; Briguglio, R. \& Briguglio, F. Esthetic integration between ceramic veneers and composite restorations: a case report. Ann. Stomatol. (Roma), 3(3-4):132-7, 2012.

Friedman, M. J. Update on porcelain veneers: an exclusive interview with Dr. Mark Friedman. Interview by Phillip Bonner. Dent. Today, 14:40-3, 1995.

Granell-Ruiz, M.; Fons-Font, A.; Labaig-Rueda, C.; MartínezGonzález, A.; Román-Rodríguez, J. L. \& Solá-Ruiz, M. F. A clinical longitudinal study 323 porcelain laminate veneers. Period of study from 3 to 11 years. Med. Ora Patol. Oral Cir. Bucal, 15(3):e5317, 2010.

Gresnigt, M.; Cune, M. S.; Schuitemaker, J.; van der Made, S. A. M.; Meisberger, E. W.; Magne, P. \& Özcan, M. Performance of ceramic laminate veneers with immediate dentine sealing: An 11 year prospective clinical trial. Dent. Mater., 35(7):1042-52, 2019.

Gresnigt, M.; Ozcan, M. \& Kalk, W. Esthetic rehabilitation of worn anterior teeth with thin porcelain laminate veneers. Eur. J. Esthet. Dent., 6:298-313, 2011.

Gurel, G.; Morimoto, S.; Calamita, M.A.; Coachman, C. \& Sesma, N. Clinical performance of porcelain laminate veneers: outcomes of the aesthetic pre-evaluative temporary (APT) technique. Int. J. Periodontics Restorative Dent., 32(6):625-35, 2012.

Javaheri, D. Considerations for planning esthetic treatment with veneers involving no or minimal preparation. J. Am. Dent. Assoc., 138(3):331-7, 2007.

Kacker, M. D.; Yarovesky, U. \& Jadali, L. Ultra-thin veneers: beautiful and natural. Dent. Today, 30:102,4-5, 2011.

Layton, D. M.; Clarke, M. \& Walton, T. R. A systematic review and meta-analysis of the survival of feldspathic porcelain veneers over 5 and 10 years. Int. J. Prosthodont., 25(6):590-603, 2012.

Lee, S. M. \& Choi, Y. S. Effect of ceramic material and resin cement systems on the color stability of laminate veneers after accelerated aging. J. Prosthet. Dent., 120(1):99-106, 2008.

Lerner, J. M. Conservative aesthetic enhancement of the maxillary anterior using porcelain laminate veneers. Pract. Proced. Aesthet. Dent., 18(6):361-6, 2006.

Martignon, S.; López-Macías, A. M.; Bartlett, D.; Pitts, N.; UsugaVacca, M.; Gamboa, L. F. \& O'Toole, S. The use of index teeth vs. full mouth in erosive tooth wear to assess risk factors in the diet: A cross-sectional epidemiological study. J. Dent., 88:103164, 2019.

Materdomini, D. \& Friedman, M. J. The contact lens effect: enhancing porcelain veneer esthetics. J. Esthet. Dent., 7(3):99-103, 1995.

McLaren, E. A. \& LeSage, B. Feldspathic veneers: what are their indications? Compend. Contin. Educ. Dent., 32(3):44-9, 2011.

Morita, R. K.; Hayashida, M. F.; Pupo, Y. M.; Berger, G.; Reggiani, R. D. \& Betiol, E. A. G. Minimally invasive laminate veneers: Clinical aspects in treatment planning and cementation procedures. Case Rep. Dent., 2016:1839793, 2016.

Nash, R. W. The contact lens porcelain veneer. Dent. Today, 22:569, 2003.

O'Toole, S. \& Mullan, F. The role of the diet in tooth wear. Br. Dent. J., 224(5):379-83, 2018.

Okida, R. C.; Vechiato Filho, A. J.; Barao, V. A. R.; Dos Santos, D. M. \& Goiato, M. C. The use of fragments of thin veneers as a restorative therapy for anterior teeth disharmony: a case report with 3 years of follow-up. J. Contemp. Dent. Pract., 13(3):41620, 2012.

Pini, N. P.; Aguiar, F. H. B.; Lima, D. A. N. L.; Lovadino, J. R.; Terada, R. S. S. \& Pascotto, R. C. Advances in dental veneers: materials, applications, and techniques. Clin. Cosmet. Investig. Dent., 4:916, 2012.

Re, D.; Augusti, G.; Amato, M.; Riva, G. \& Augusti, D. Esthetic rehabilitation of anterior teeth with laminates composite veneers. Case Rep. Dent., 2014:849273, 2014.
Sá, T. C. M.; de Carvalho, M. F. F.; de Sá, J. C. M.; Magalhães, C. S.; Moreira, A. N. \& Yamauti, M. Esthetic rehabilitation of anterior teeth with different thicknesses of porcelain laminate veneers: An 8-year follow-up clinical evaluation. Eur. J. Dent., 12(4):5903, 2018.

Schoenfeld, C. The lumineers ${ }^{\circledR}$ no prep technique for porcelain laminate veneers. The Lumineers $₫$ by Cerinate $₫$ : The Most Significant Advancement in 9,000 Years of Dentistry, 2006. Available from: www.ksdental.nl/?download=schoenfeld paper.pdf

Strasseler, H E. Minimally invasive porcelain veneers: indications for a conservative esthetic dentistry treatment modality. Gen. Dent., 55(7):686-94, 2007.

Veneziani, M. Ceramic laminate veneers: clinical procedures with a multidisciplinary approach. Int. J. Esthet. Dent., 12(4):426-48, 2017.

Corresponding author:

Eduardo Borie Echevarría

Av. Francisco Salazar 01145

Dental School

Universidad de La Frontera

Temuco

CP: 4811230

CHILE

E-mail: eduardo.borie@ufrontera.cl 